\title{
Luring Rivals' Staff: Employer Brand Image According to Current and Potential Employees in Turkish Service Industry
}

\author{
Çağla Pınar BOZOKLU iDa \\ a Başkent University, Ankara, Turkey.cutkug@hotmail.com
}

\begin{tabular}{|c|c|}
\hline ARTICLE INFO & ABSTRACT \\
\hline Keywords: & Purpose - Employer branding not only brings competitive differentiation, but also contributes to \\
\hline Employer brand & appeal most competent employees in the markets. However, rivals' staff as potential employees \\
\hline Current employee & have been overlooked in the existing corporate branding literature. The aim of the research is to \\
\hline Rivals' employee & analyze employer brand image among not only current employees, but also rivals' employees \\
\hline Turkey & within the concept of competitive advantage, and then to determine the most explanatory factor. \\
\hline Service & $\begin{array}{l}\text { Design/Methodology/Approach - Within the Turkish service industry, the air transportation, } \\
\text { communication and banking markets were given priority by the reason that publicly traded, }\end{array}$ \\
\hline Received 31 January 2018 & national corporates are predominant in them. Corporate reputation scale, has a facet called "Good \\
\hline Revised 15 June 2019 & Employer", developed by Walsh and Betty (2007), is conducted to 187 sector employees by using \\
\hline Accepted 25 June 2019 & $\begin{array}{l}\text { purposive sampling method. A pretest is conducted to } 112 \text { participants for measuring the } \\
\text { reliability of the scale items. Cronbach Alpha was calculated as } .913 \text {. }\end{array}$ \\
\hline \multirow[t]{2}{*}{$\begin{array}{l}\text { Article Classification: } \\
\text { Research Article }\end{array}$} & $\begin{array}{l}\text { Findings - The findings show that employer brands of Pegasus, Vodafone and İş Bankası are } \\
\text { stronger than their competitors. According to factor analyses, "perceiving as the best place for } \\
\text { work" is the most explanatory factor on employer branding for both service industries. }\end{array}$ \\
\hline & $\begin{array}{l}\text { Discussion: As a practical implication, Turkish service industry may have a role in the Belt and } \\
\text { Road Initiative. The Belt and Road may create several opportunities of mergers and joint } \\
\text { ventures, which provide relative competitive advantage to domestic firms in the global market. }\end{array}$ \\
\hline
\end{tabular}

\section{Introduction}

According to Freeman (1984), "If organizations want to be effective, they will pay attention to all and only those relationships that can affect or be affected by the achievement of the organization's purposes.". Within this context, attractiveness image of a business for current and potential employees is an eye-catching concept.

Ambler and Barrow (1996: 187) are the first researchers who coined the employer branding and identified as "the package of functional, economic and psychological benefits provided by employment". The concept, which can be discussed in terms of both marketing and management, has begun to develop in 2000s. These fields are interlocked in many ways though they require a distinctive expertise. In the literature, majority of researches focus on employer brand in the context of either organizational behavior or brand management (i.e. in organizational behavior or HR perspective: Edwards, 2009; Martin et al., 2011; Sutherland et al., 2002; Alnıaçık and Alnıaçık, 2012; etc. In brand management: Foster et al., 2010; Berthon et al., 2005; Knox and Freeman, 2006; Gaddam, 2008; Rampl and Kenning, 2014; etc.). However, this paper examines the concept in a competitive manner by integrating both of them.

\section{Literature Review}

\subsection{Employer branding as a competitive advantage}

Researchers like Hart and Murphy $(1998)$ and Ind $(1997,1998)$ suggest that stronger corporate brands able to recruit and retain in their hands the best employees. This idea has been developed as the concept of employer brand in time (i.e. Ambler and Barrow, 1996; Backhaus and Tikko, 2004; Berthon et al., 2005; Carrington, 2007; Moroko and Uncles, 2008). 
As Barney (1991) stated, resource based view admits that features of a firm's sources can bring to sustainable competitive advantage. The theoretical foundation of employer branding is depending on the idea that human capital contributes value to the firm and through investing human capital, firm performance can be enhanced (Backhaus and Tikko, 2004: 503). Following this, alignment between organization's identification and employee's values must also be met (Hatch and Shultz, 2001) so that a corporate brand's promise and values delivered by employees can promote the communication of a consistent brand image and its associations to external stakeholders (Berry 1995, 2000; Bitner 1992; Ind, 1998). Thereby, it is expected that stronger employer brand sustains competitive advantage by enhancing firm's relative performance.

Backhous and Tikko (2004:502) emphasize competitive aspect as stating that employer branding offers differentiation of a firm's identity as an employer from its competitors and it emphasizes the unique perspectives of the firm's employment offerings or environments. Researchers like Edwards (2009: 6), Martin and Beaumont (2003: 15), Dell et al. (2001: 10), Foster et al., (2010) enrich the content of employment offerings by mentioning "potential recruits". Actually these researches remarked the potential employees in the external environment but yet they did not refer rivals' staff as a potential hire opportunity. Similarly, current employees are accepted as internal customers in the perspective of internal marketing (Ewing and Caruana, 1999; George and Gronroos, 1989; George, 1990; Berry et al., 1991) however this perspective has also ignoring the role of rivals' valuable staff in the recruitment processes. Indeed, "potential employees as a key stakeholder group of the corporate brand have been overlooked in the existing corporate branding literature" (Hatch and Shultz, 2003). If in the near future, competition for the transformational employees will be as tortuous as competition for customers (Berthon et al., 2005: 167), businesses have to face with their employer brand image in a competitive way.

According to Lloyd (2002) employer brand is the "sum of a company's efforts to communicate to existing and prospective staff that it is a desirable place to work". Employer branding not only brings competitive differentiation but also contributes to appeal most competent employees in the markets. Because of that, attractiveness of corporate brands on the eye of their own employees is not enough to explain employer brand image aggregately. Some researches indicate the role of recent graduates as potential recruits although they have no influence on the transformational strategical changes. Their authority and responsibility area does not generally sufficient for sustaining valuable contributions. Their priority could be defined as to adapt and adopt the dominant organizational culture. On the other hand, staff for middle and top levels are sometimes recruited from the external environment from well-experienced and competent individuals in the same or similar industries. Actually they are accepted as the competitive advantage of rivals for creating innovations in the market implications. Compare to freshmen in the business world, they have both transformational experience, authority and responsibility area for strengthening the corporate brand equity. Therefore, perception of potential employees such as rival's staff also should be taken into consideration. Thus it is hypothesized that:

$H_{1}=$ Employer brand images of businesses in the service industry statistically differ depending on the perceptions of current employees and rivals' employees.

$H_{1 a}=$ Employer brand images of businesses in air transportation market statistically differ depending on the perceptions of current employees and rivals' employees.

$H_{1 b}=$ Employer brand images of businesses in communication market statistically differ depending on the perceptions of current employees and rivals' employees.

$H_{1 c}=$ Employer brand images of businesses in banking market statistically differ depending on the perceptions of current employees and rivals' employees.

On the other hand, Van Riel and Fombrun (2007) emphasize the role of similarity between the stakeholders' perception of an organization and the essence of the organization telling about itself. If there is an imbalance situation in this equation, corporate reputation will be influenced negatively. Having a durable reputation will protect the organization from the occasional glitch, but a consistent difference or gap between them will cause lasting damage. Within the context of employer branding, perceptions of current employees may be accepted as the aspects of internal image. Because it is broadly admitted that expectations of employees may be shaped by the organizational culture predominantly shared. Additionally, perceptions of rivals' 
employee should be considered as the aspects of external image. Sutherland, Torricelli and Karg (2002: 14) supported this assumption by stating that "employer branding uses aspects of corporate identity and reputation specifically to achieve the multiple objectives of human resources management". Balmer (1998) reveals that a brand's identity need to be clearly understood and each stakeholder's perspective of these perceptions needs to be measured. Within the context of all these aspects, the potential gaps have to be considered as a threat (Aaker, 1996; de Chernatony, 1999; Bickerton, 2000; Harris and de Chernatony, 2001).

However, employer brand image is a vulnerable concept that may be significantly influenced by the macro environmental factors such as economic conditions and cross-cultural differences. There is limited research on exploring the indicators of employer brand image. For instance, Herman and Giola (2000) determined eight factors such as company reputation, company culture, enlightened leadership, treatment to people, opportunity for career growth, meaningful work, compensation and benefits. Simons (2000) addressed the importance of motivational work environment (Sutherland et al., 2002). Moreover, Knox and Freeman (2006) identified the factor "really cares about their employees as individuals" as a key attribute. Of course, all these measures are influential on employer brand; however, in the decrepit economic conditions some of them may not have the precedence. Turkey has gone through several depressing economic crises after the 1960s, which is known as the wealthiest and democratic period in the history of Turkish Republic. According to data of Turkish Statistical Institute (2019), the rate of unemployment has been rising permanently since the beginning of the 21th century. Under these circumstances, the demands of the work force have focused mainly to the physiological and safety needs as mentioned by Maslow's Needs Hierarchy.

But it is thought that "being the greatest place to work" (Sutherland et al., 2002) is the core of the concept and it should not alter depending on cross-cultural differences. Most of the researches have focused on the value alignment among organizations and employees (i.e. Alnıaçı and Alnıaçı, 2012) instead of the expectations of employees. Substantially, the employer brand image is about the perception of the corporate's offerings by a specific stakeholder group. Therefore, priorities of the current and potential employees should be considered as expectations from organization instead of corporate's values. Accordingly, it is assumed that:

$H_{2}=$ "Being the greatest place to work" is the most effective variable on employer brand image in the service industry.

\section{Method}

The primary aim of the research is to analyze employer brand image of service businesses that are publicly traded depending on the perceptions of current employees and rivals' employees. Besides, the most explanatory factor for employer branding concept also determined.

In this research, researcher focused to Turkish service industry by the reason that the share of Turkish service industry in the national economy has expanded from \%35 to \%61 (Tekin Koru ve Dinçer, 2018) in the last 50 years. Also, air transportation, communication and banking markets were preferred because the national corporates are predominant in them.

Corporate reputation scale, has a facet called "Good Employer", developed by Walsh and Betty (2007), was conducted to 191 employees by using purposive and snowball sampling method. The items of "good employer" facet examine the pre-emptible expectations such as working atmosphere, conditions of treatment to employees, leadership excellence, maintaining high standards, recruiting standards and degree of attention to needs. These measures present similarity with the literature. As Nunnally (1978) stated, scale was found reliable (Cronbach Alpha=.913) depending on the findings of pretest which was conducted to 112 participants. IBM SPSS Statistics 25 software program was used for all tests with the significance level of .05.

At last, 187 survey were gathered in the research. As only four survey ( 2 current employees and 2 rivals' employees) were return for Turk Telekom, it was excluded from the sample. Moreover, some participants did not answer several demographic questions. Their demographics are presented in Table 1. 
C. P. Bozoklu 11/2 (2019) 1270-1279

Table 1. Demographics

\begin{tabular}{|c|c|c|c|c|c|c|c|c|c|c|c|}
\hline & & Akbank & Garanti & İş Bankası & $\begin{array}{c}\text { Yapı ve Kredi } \\
\text { Bankası }\end{array}$ & Pegasus & $\begin{array}{l}\text { Turkish } \\
\text { Airlines }\end{array}$ & Turkcell & Vodafone & Total & $\%$ \\
\hline \multirow[b]{2}{*}{ Gender } & Female & 9 & 7 & 9 & 24 & 12 & 13 & 3 & 9 & 86 & 50.5 \\
\hline & Male & 2 & 6 & 8 & 19 & 20 & 4 & 12 & 13 & 84 & 49.5 \\
\hline \multicolumn{2}{|c|}{ Total } & 11 & 13 & 17 & 43 & 32 & 17 & 15 & 22 & 170 & 100 \\
\hline \multirow[b]{6}{*}{ Age } & $18-25$ & 0 & 1 & 3 & 12 & 3 & 7 & 3 & 8 & 37 & 20 \\
\hline & $26-32$ & 6 & 8 & 3 & 17 & 11 & 9 & 10 & 8 & 72 & 38 \\
\hline & $33-42$ & 5 & 4 & 8 & 7 & 14 & 10 & 1 & 5 & 54 & 29 \\
\hline & $43-50$ & 0 & 0 & 3 & 5 & 4 & 6 & 1 & 1 & 20 & 11 \\
\hline & $51-65$ & 0 & 0 & 0 & 1 & 0 & 2 & 0 & 0 & 3 & 1.5 \\
\hline & $65+$ & 0 & 0 & 0 & 1 & 0 & 0 & 0 & 0 & 1 & .5 \\
\hline \multicolumn{2}{|c|}{ Total } & 11 & 13 & 17 & 43 & 32 & 34 & 15 & 22 & 187 & 100 \\
\hline \multicolumn{2}{|r|}{ Elementary } & 0 & 0 & 0 & 0 & 0 & 0 & 1 & 0 & 1 & .5 \\
\hline \multirow[b]{4}{*}{ Education } & \begin{tabular}{|l|} 
Middle \\
School
\end{tabular} & 0 & 0 & 2 & 0 & 4 & 1 & 0 & 1 & 8 & 2.5 \\
\hline & High School & 0 & 0 & 5 & 1 & 5 & 8 & 7 & 11 & 37 & 20 \\
\hline & \begin{tabular}{|c|} 
Graduate \\
Degree
\end{tabular} & 9 & 12 & 10 & 34 & 22 & 21 & 6 & 9 & 123 & 68 \\
\hline & \begin{tabular}{|c|} 
Post \\
Graduate \\
Degree
\end{tabular} & 2 & 1 & 0 & 8 & 1 & 4 & 1 & 1 & 18 & 9 \\
\hline \multicolumn{2}{|c|}{ Total } & 11 & 13 & 17 & 43 & 32 & 34 & 15 & 22 & 187 & 100 \\
\hline \multirow[b]{6}{*}{ Income } & \begin{tabular}{|l|}
$0-2000 \mathrm{TL}$ \\
\end{tabular} & 0 & 0 & 0 & 1 & 0 & 2 & 1 & 0 & 4 & 2.5 \\
\hline & \begin{tabular}{|c|}
$2001-5000$ \\
TL
\end{tabular} & 2 & 3 & 9 & 15 & 15 & 11 & 5 & 8 & 68 & 43 \\
\hline & \begin{tabular}{|c|}
$5001-$ \\
$10000 \mathrm{TL}$ \\
\end{tabular} & 4 & 5 & 3 & 18 & 13 & 11 & 7 & 8 & 69 & 43 \\
\hline & \begin{tabular}{|c|}
$10001-$ \\
$15000 \mathrm{TL}$ \\
\end{tabular} & 2 & 0 & 0 & 4 & 1 & 2 & 0 & 3 & 12 & 7.5 \\
\hline & \begin{tabular}{|c|}
$15001-$ \\
$20000 \mathrm{TL}$ \\
\end{tabular} & 1 & 0 & 0 & 0 & 1 & 0 & 0 & 0 & 2 & 1 \\
\hline & $20001+\mathrm{TL}$ & 1 & 0 & 0 & 2 & 0 & 0 & 0 & 1 & 4 & 3 \\
\hline \multicolumn{2}{|c|}{ Total } & 10 & 8 & 12 & 40 & 30 & 26 & 13 & 20 & 159 & 100 \\
\hline
\end{tabular}

\section{Findings}

Findings are classified as the Normality test and Employer brand images of businesses in the air transportation market, communication market and banking markets.

\subsection{Findings of normality tests}

The data of scale items were tested by Kolmogorov Smirnov and Shapiro-Wilk whether they shown a normal distribution. According to results, data did not normally distribute $\left(p^{\text {Kolmogorov }} \leq .001, p^{\text {Shapiro }} \leq .001\right)$. According to that, non-parametric tests were conducted for the research hypotheses.

\subsection{Analyses of employer brands of businesses in terms of their markets}

Findings on whether employer brands of businesses differ depending on the perceptions of current employees and rivals' employees in terms of air transportation, communication and banking markets are respectively presented under the following sub-headings.

\subsubsection{Employer brand images of businesses in air transportation market}

In Turkish air transportation market, publicly traded businesses are Turkish Airlines and Pegasus. At first, their employer brand images were analyzed by Mann Whitney U test without classifying stakeholders as current employees and rivals' employees. As seen in Table 2, statistically meaningful differences were found for all items with the exception of first one. The employer brand image of Pegasus was found stronger than Turkish Airlines for all these items 
C. P. Bozoklu 11/2 (2019) 1270-1279

Table 2. Employer Brand Images of Air Transportation Businesses in Turkey

\begin{tabular}{|c|c|c|c|c|c|c|}
\hline Employer Brand Image & Brands & & $\mathbf{n}$ & $\mathbf{R}$ & $\mathbf{U}$ & p \\
\hline \multirow[t]{3}{*}{ 2. Seems to treat its people well } & Pegasus & & 32 & 40.83 & 309.500 & .001 \\
\hline & $\begin{array}{l}\text { Turkish } \\
\text { Airlines }\end{array}$ & & 34 & 26.60 & & \\
\hline & & Total & 66 & & & \\
\hline \multirow[t]{3}{*}{ 3. Seems to have excellent leadership } & Pegasus & & 32 & 41.89 & 275.500 & $\leq .001$ \\
\hline & $\begin{array}{l}\text { Turkish } \\
\text { Airlines }\end{array}$ & & 34 & 25.60 & & \\
\hline & & Total & 66 & & & \\
\hline \multirow{3}{*}{$\begin{array}{l}\text { 4. Seems to maintain high standards in the } \\
\text { way that it treats people. }\end{array}$} & Pegasus & & 32 & 42.16 & 267.000 & $\leq .001$ \\
\hline & $\begin{array}{l}\text { Turkish } \\
\text { Airlines }\end{array}$ & & 34 & 25.35 & & \\
\hline & & Total & 66 & & & \\
\hline \multirow[t]{3}{*}{ 5. Seems to have good employees. } & Pegasus & & 32 & 40.63 & 316.000 & .002 \\
\hline & $\begin{array}{l}\text { Turkish } \\
\text { Airlines }\end{array}$ & & 34 & 26.79 & & \\
\hline & & Total & 66 & & & \\
\hline \multirow{3}{*}{$\begin{array}{l}\text { 6. Has management who seems to pay } \\
\text { attention to the needs of its employees. }\end{array}$} & Pegasus & & 32 & 43.06 & 238.000 & $\leq .001$ \\
\hline & $\begin{array}{l}\text { Turkish } \\
\text { Airlines }\end{array}$ & & 34 & 24.50 & & \\
\hline & & Total & 66 & & & \\
\hline \multirow[t]{3}{*}{ 7. Seems to be well-managed. } & Pegasus & & 32 & 41.20 & 297.500 & .001 \\
\hline & $\begin{array}{l}\text { Turkish } \\
\text { Airlines }\end{array}$ & & 34 & 26.25 & & \\
\hline & & Total & 66 & & & \\
\hline
\end{tabular}

Secondarily, employer image of each brand is analyzed depending on the perceptions of their own employees and their rivals' employees. According to results of Mann Whitney U tests, statistically meaningful differences were found. Current employees perceive the employer brand image of Pegasus stronger compared to its rivals' (Turkish Airlines) employees $\left(p^{i 2}=.023, U^{\mathrm{i} 2}=21,000 ; p^{\mathrm{i} 3}=.004\right.$, $\left.U^{\mathrm{i} 3}=10,000 ; p^{\mathrm{i} 4}=.004, U^{\mathrm{i} 4}=9,000 ; p^{\mathrm{i} 5}=.002, U^{\mathrm{i} 5}=10,000 ; p^{\mathrm{i} 6}=.003, U^{\mathrm{i} 6}=9,000 ; p^{\mathrm{i} 7}=.003, U^{\mathrm{i} 7}=8,500\right)$.

On the contrary, no statistically meaningful difference was found between the perceptions of its current employees and rivals' employees for employer brand image of Turkish Airlines. Its rivals' (Pegasus) employees perceive the employer brand image of Turkish Airlines as stronger as current employees $\left(p^{i 1}=\right.$ $.404, U^{\mathrm{i} 1}=115,500 ; p^{i 2}=.215, U^{\mathrm{i} 2}=107,500 ; p^{\mathrm{i} 3}=.879, U^{\mathrm{i} 3}=132,500 ; p^{\mathrm{i} 4}=.115, U^{\mathrm{i} 4}=95,000 ; p^{\mathrm{i} 5}=.310, U^{\mathrm{i} 5}=109,000$; $\left.p^{\mathrm{i}}=.749, U^{\mathrm{i} 6}=128,000 ; p^{\mathrm{i} 7}=.424, U^{\mathrm{i}}=116,500\right)$. According to these findings, H1a was accepted for Pegasus brand whereas it was rejected for Turkish Airlines.

Secondarily, factor analysis was done for determining the most explanatory factor for employer brand image in the air transportation market. Depending on the KMO value, data was found as suitable for the factor analysis $(\mathrm{KMO}=.890, \mathrm{p} \leq .001)$. The first item of the scale, "looks like a good company to work for", is able to explain the employer brand image as $\% 78$.

4.2.2. Employer brand images of businesses in communication market

In Turkish communication market, publicly traded businesses are Turkcell and Turk Telekom. Since Vodafone is one of the most preferred communication brands in Turkey market, it was also included to the research sample even though it is not traded at the İstanbul Stock Exchange. On the other hand, Turk Telekom was excluded from the sample in due to only four questionnaires (2 current employees and 2 rivals' employees) returned.

At first, their employer brand images were analyzed by Mann Whitney $U$ test without classifying stakeholders as current employees and rivals' employees. As seen in Table 3, statistically meaningful 
differences were found for only last item. The employer brand image of Vodafone was found stronger than Turkcell because it is believed that Vodafone "seems to be well-managed". However, their other employer brand items are perceived similar by the key stakeholder groups.

Table 3. Employer Brand Images of Communication Businesses in Turkey

\begin{tabular}{lccccc}
\hline Employer Brand Image & Brands & $\mathbf{n}$ & $\mathbf{R}$ & $\mathbf{U}$ & $\mathbf{p}$ \\
\hline 7. Seems to be well-managed. & Vodafone & 22 & 21.64 & 107,000 & .046 \\
& Turkcell & 15 & 15.13 & & \\
& Total & 37 & & & \\
\hline
\end{tabular}

Secondarily, employer brand images of Vodafone and Turkcell brands are analyzed depending on the perceptions of their own employees and their rivals' employees. According to results of Mann Whitney $U$ tests, statistically meaningful differences were found. Current employees perceive the employer brand image of Vodafone stronger compared to its rivals' (Turkcell) employees $\left(p^{i 1}=.049, U^{i 1}=22,500 ; p^{i 2}=.023\right.$, $\left.U^{\mathrm{i} 2}=18,500 ; p^{\mathrm{i} 3}=.017, U^{\mathrm{i} 3}=17,000 ; p^{\mathrm{i} 4}=.008, U^{\mathrm{i} 4}=13,000\right)$. According to them, Vodafone more "looks like a good company to work for", "seems to treat its people well", "seems to have excellent leadership" and "seems to maintain high standards in the way that it treats people".

Similarly, statistically meaningful differences were found between the perceptions of its current employees and rivals' employees for employer brand image of Turkcell. But the influential items are mostly different. Current employees perceive the employer brand image of Turkcell stronger compared to its rivals' (Vodafone) employees $\left(p^{i 1}=.033, U^{\mathrm{i} 1}=7,500 ; p^{\mathrm{i} 3}=.035, U^{\mathrm{i} 3}=8,000 ; p^{\mathrm{i} 5}=.001, U^{\mathrm{i} 5}=2,000 ; p^{\mathrm{i} 6}=.020, U^{\mathrm{i} 6}=6,000 ; p^{\mathrm{i} 7}=\right.$ $\left..039, U^{i 7}=8,000\right)$. According to them, Turkcell "looks like a good company to work for", "seems to have excellent leadership", "seems to have good employees", "has management who seems to pay attention to the needs of its employees", and "seems to be well-managed". Therefore, H1b was accepted for communication market.

Also, factor analysis was done for determining the most explanatory factor for employer brand image in the communication market. Depending on the KMO value, data was found as suitable for the factor analysis $(\mathrm{KMO}=.787, \mathrm{p} \leq .001)$. The first item of the scale, "looks like a good company to work for", is able to explain the employer brand image as \% 77.

\subsubsection{Employer brand images of businesses in banking market}

In Turkish banking market, publicly traded businesses are Akbank, Denizbank, QNB Finansbank, Şekerbank, Türkiye Garanti Bankası, Türkiye Halk Bankası, Türkiye İş Bankası, Türkiye Vakıflar Bankası and Yapı ve Kredi Bankası. As another limitation, only the employees of İş Bankası, Garanti Bankası, Yapı ve Kredi Bankası and Akbank could be reached.

At first, their employer brand images were analyzed by Kruskal Wallis $\mathrm{H}$ test without classifying stakeholders as current employees and rivals' employees. As seen in Table 4, statistically meaningful difference was found only for the second item. The employer brand image of İş Bankası was stronger than the others because it is accepted as "seems to treat its people well". However, their other employer brand items are perceived similarly by the key stakeholder groups.

Table 4. Employer Brand Images of Banks in Turkey

\begin{tabular}{llllll}
\hline Employer Brand Image & Brands & $\mathbf{n}$ & $\mathbf{R}$ & $\boldsymbol{\chi}^{\mathbf{2}}$ & $\mathbf{p}$ \\
\hline 2. Seems to treat its people well. & İş Bankası & 17 & 48.97 & 8,939 & .030 \\
& Garanti Bankası & 13 & 45.04 & & \\
& Yapı ve Kredi Bankasi & 43 & 43.64 & & \\
& Akbank & 11 & 25.05 & & \\
& Total & 84 & & & \\
\hline
\end{tabular}

Following this, employer brand image of all banks are individually analyzed depending on the perceptions of their own employees and their rivals' employees. According to results of Mann Whitney U tests, statistically meaningful differences were found for İş Bankası. Current employees perceive the employer 
brand image of İş Bankası as "looks like a better company to work for" compared to its rivals' (other banks) employees $\left(p^{i 1}=.023, U^{i 1}=10,000\right)$.

Statistically meaningful differences were found between the perceptions of its current employees and rivals' employees for employer brand image of Garanti Bankasi. Current employees perceive the employer brand image of Garanti Bankası as "looks like a better company to work for" and "seems to be more wellmanaged" compared to its rivals' (other banks) employees ( $p^{i 1}=.026, U^{\mathrm{i} 1}=3,500 ; p^{\mathrm{i} 7}=.013, U^{\mathrm{i} 7}=1,000$ ).

Statistically meaningful differences were measured between the perceptions of its current employees and rivals' employees for employer brand image of Yapı ve Kredi Bankası. Current employees perceive the employer brand image of Yapı ve Kredi Bankası as "looks like a better company to work for" compared to its rivals' (other banks) employees $\left(p^{i 1}=.021, U^{i 1}=29,500\right)$.

Also, statistically meaningful differences were found between the perceptions of its current employees and rivals' employees for employer brand image of AkBank. Current employees perceive the employer brand image of Akbank as "looks like a better company to work for", "seems to treat its people well", "seems to have excellent leadership", "seems to maintain high standards in the way that it treats people" and "seems to be well-managed" compared to its rivals' (other banks) employees $\left(p^{-1}=.004, U^{\mathrm{i} 1}=1,000 ; p^{\mathrm{i} 2}=.044\right.$, $\left.U^{\mathrm{i} 2}=3,000 ; p^{\mathrm{i} 3}=.044, U^{\mathrm{i} 3}=5,000 ; p^{\mathrm{i} 4}=.010, U^{\mathrm{i} 4}=1,500 ; p^{\mathrm{i} 7}=.039, U^{\mathrm{i} 7}=4,500\right)$. Depending on these findings, H1c was accepted.

At last, factor analysis was done for determining the most explanatory factor for employer brand image in the banking market. Depending on the KMO value, data was measured as suitable for the factor analysis $(\mathrm{KMO}=.895, \mathrm{p} \leq .001)$. The first item of the scale, "looks like a good company to work for" is able to explain the employer brand image as \% 67. According to the results of all factor analyses, $\mathrm{H} 2$ is also accepted.

\section{Conclusion and Discussion}

In this research, several employer brands in Turkish service industries were analyzed depending on the perceptions of their own employees and rival businesses' employees. It is argued that the perceptions of rivals' employees are crucial for the strengthening employer brand image as well as current employees. Also, results support the largely accepted judgement related to employer branding concept that employee of a business should believe her/his company is the best place for working. This judgement may be also interpreted as that organizational commitment of employees and the value of employer branding are positively related.

The findings of employees in Turkish air transportation market show that employer brand of Pegasus is stronger than Turkish Airlines for almost every aspect. Pegasus is accepted as more successful in the leadership, managerial effectiveness, effective recruitment and the treatment to staff contexts. It should be reminded that the research was conducted before the Pegasus accident, which was occurred in AnkaraTrabzon flight on $13^{\text {th }}$ January 2018. Therefore, evaluations do not represent that situation's descendants. On the contrary, the employer brand image of Turkish Airlines is similar for its employees and rivals' employees. This result is very unpredictable and extraordinary because it has not seen for any other businesses in the research sample. Yet some researchers had warned about the threat that the difference between the perception of a corporate brand by its stakeholders should be avoided (Aaker, 1996; de Chernatony, 1999; Bickerton, 2000; Harris and de Chernatony, 2001), the similarity between the perceptions may be occurred by the reason that Turkish Airlines is a state-funded brand and it offers higher economic benefits. It should be also noted that Turkey has going through a deepening economic crises and lose in value of income level has leading the labor market to prefer working under the state guarantee. Antecedents of this result may be searched in detailed in due to identify the effective variables on the employer brand image of public enterprises.

The findings of employees in Turkish communication market demonstrate that employer brand of Vodafone is stronger than Turkcell by the reason that it has been managed better. Both brands have similar employer brand images within the contexts of leadership and good place for work. Vodafone offers to its employees "a better treatment by the managerial staff" whereas Turkcell offers to its employees "a management who pay attention to the needs". Both offers may be considered as the same however, concrete and right identification of employee's needs is a must for putting into practice them. Therefore, "a better treatment by the 
managerial staff" offer may be considered as more comprehensive attribute with a base of internal corporate communication.

The findings of employees in Turkish banking sector indicate that employer brand of İş Bankası is stronger than the other brands by reason that it is perceived as a better place for work. As an eye-catching finding, the employees of Akbank seem their own corporate more reputable because it is not only a good place for work, but also successful at leadership, managerial effectiveness and treating kindly to employees.

According to factor analyses, "perceiving as the best place for work" is the most explanatory factor on employer branding for both service industries. This result presents supportive evidence for the research of Sutherland, Torricelli and Karg (2002). As stated in the literature, variables that influence the perception of "best place for work" are diverse (i.e. Herman and Gioia, 2001; Simons, 2000 and Knox and Freeman, 2006). They may differ from one labour market (or/and country) to another by the driving force of the macro environmental factors (i.e. economic recession, higher disguised unemployment rate, lower unionization rate etc.). However, future researches can examine the context of "the best work place".

As a practical implication, Turkish banking industry may have a role in the Belt and Road Initiative. The Belt and Road Initiative is a comprehensive and ambitious development campaign through which China wants to boost trade and stimulate economic growth across Asia and beyond (Phillips, 2017). The first priority of the project is declared as infrastructure connectivity with a US $\$ 40$ billion Silk Road Fund support. However, it is just a first step of The "Five Links" which consists of policy coordination, capacity building, facilitation of trade and investment, financial cooperation and people. Turkey is the one of the selected countries by Fung Business Intelligence Centre. After China (US\$ 9240.3 billion GDP), Germany (US\$ 3730.3 billion GDP), Italy (US\$ 2149.5 billion GDP), Russia (US\$ 2096.8 billion GDP), and India (US\$ 1876.8 billion GDP); it had created US\$ 822.1 billion GDP with a US\$ 582.7 million household consumption in 2013. Turkey is not only a great market, but it is also a founding member of the Asian Infrastructure Investment Bank which controls the right to establish the rules for the bank's activities (Chin et al., 2015).

Financial integration was emphasized by Fung Business Intelligence Centre (2015) as the process of which will create demand for more professional services in financial and related sectors. İş Bankası may present valuable contributions to build currency stability or investment and financing systems by its reliable brand image.

Depending on the co-operation of stronger employer brands, several win-win situations may occur. In the micro perspective, employees working for a stronger employer brand acquire what they deserve in their social and working life. It should be noticed that employees play a critical role on building and maintaining corporate brand equity both at their work atmosphere and in their interactions with family and friends (Morokane et al., 2016). Therefore, the reliability and prestige of Asian trade will be spread in waves across the region. After all, corporates get higher market prices and permanent positions in the global market against to the giants by means of their reputation. In the macro perspective, developing countries in Silk Road region will be experienced immense economic growth through the co-operations and the integrations of communication, air transportation (civil-oriented and logistic-oriented) and financial service markets. The businesses in these countries benefit from the know-how transfer of technologies and managerial competence, funds and enhancement of the employment opportunities. It should be noticed that sustainable economic growth could not be considered without satisfied society. The concept of employer branding brings delayed labor needs to the competent work force.

In the future, country-oriented studies on work values and on work expectations in a manner of internal marketing that identify the employer branding should be conducted for understanding the concept more clearly. Especially, countries of businesses, which volunteer to co-operations through the Belt and Road Initiative project, are recommended as a research sample.

\section{Declaration of Interest Statement}

This research did not receive any specific grant from funding agencies in the public, commercial or not for profit sectors. 


\section{References}

Aaker, D.A. (1996). Building Strong Brands. New York: The Free Press.

Alnıaçık, E., and Alnıaçık, Ü. (2012). Identifying Dimensions of Attractiveness in Employer Branding: Effects of Age, Gender, and Current Employment Status, Procedia-Social and Behavioral Sciences, 58, 13361343.

Ambler, T. and Barrow, S. (1996). The Employer Brand, The Journal of Brand Management 4 (3), 85-206.

Backhaus, K. and Tikoo, S. (2004). Conceptualizing and Researching Employer Branding, Career Development International, 9 (4/5), $501-517$.

Balmer, J. M. (1998). Corporate İdentity and the Advent of Corporate Marketing, Journal of Marketing Management, 14 (8), 963-996.

Barney, J.B. (1991). Firm Resources and Sustained Competitive Advantage, Journal of Management, 17,99-120.

Berry, L. L., Conant, J. S. and Parasuraman, A. (1991). A framework for conducting a services marketing audit, Journal of the Academy of Marketing Science, 19 (3), 255-268.

Berry, L.L. (1995). Relationships Marketing of Services, Growing İnterest, Emerging Perspectives, Journal of Academy Marketing Science, 23 (4), 236-45.

Berthon, P., Ewing, M., and Hah, L.L. (2005). Captivating Company: Dimensions of Attractiveness in Employer Branding, International Journal of Advertising, 24(2), 151-172.

Bickerton, D. (2000). Corporate reputation Versus Corporate Branding: The Realist Debate, Corporate Communications, 1, 42-48.

Bitner, M.J. (1992). Servicescapes: The İmpact of Physical surroundings on Customers and Employees, Journal of Marketing, 56, 57-71.

Carrington, L. (2007). Designs on the Dotted Line People, Management Magazine (18 October): 36 -39.

de Chernatony, L. (1999). Brand Management through Narrowing the gap between Brand Identity and Brand Reputation, Journal of Marketing Management, 15 (1-3), 157-180.

Chin, H., Lau, F., He, W., and Cheung, T. (2015). The Silk Road Economic Belt and the 21st Century Maritime Silk Road. Fung Business Intelligence Centre, New York.

Dell, D., Ainspan, N., Bodenberg, T., Troy, K., and Hickey, J. (2001). Engaging employees through your brand. The Conference Board 22 May.

Edwards, M.R. (2009). An integrative review of employer branding and OB theory, Personnel Review 39 (1), 5 23.

Ewing, M. T. and Caruana, A. (1999). An internal marketing approach to public sector management: the marketing and human resources interface, International Journal of Public Sector Management, 12 (1), 17 29.

Foster, C., Punjaisri, K., and Cheng, R. (2010). Exploring the Relationship between Corporate, Internal and Employer Branding, Journal of Product \& Brand Management 19 (6), 401-409.

Freeman, R.E. (1984). Strategic Management: A Stakeholder Approach. Boston: Pitman.

Gaddam, S. (2008). Modeling Employer Branding Communication: The Softer Aspect of HR Marketing Management, ICFAI Journal of Soft Skills 2(1), 45-55.

George, W. R. and Gronroos, C. (1989). Developing customer-conscious employees at every level: internal marketing, Handbook of Services Marketing, 29-37.

George, W. R. (1990). Internal marketing and organizational behavior: A partnership in developing customer-conscious employees at every level, Journal of Business Research, 20 (1), 63-70. 


\section{P. Bozoklu 11/2 (2019) 1270-1279}

Harris, F. and de Chernatony, L. (2001). Corporate Branding and Corporate Brand Performance, European Journal of Marketing, 35 (3/4), 441-456.

Hart, S. and Murphy, J. (1998). Brands: The New Wealth Creators. Basingstoke: Macmillan Business.

Hatch, M.J., and Schultz, M. (2001). Are the Strategic Stars Aligned for Your Corporate Brand?, Harvard Business Review February, 128-134.

Hatch, M. and Schultz, M. (2003). Bringing the corporation into corporate branding, European Journal of Marketing, 37 (7/8), 1041-1064.

Herman, R.E., and Gioia, J. L. (2001). Helping Your Organization Become an Employer of Choice, Employment Relations Today 28 (2), 63-78.

Ind, N. (1997). The Corporate Brand. Basingstoke: Macmillan Business.

Ind, N. (1998). An Integrated Approach to Corporate Branding, The Journal of Brand Management 5 (5), 323329.

Knox, S., and Freeman, C. (2006). Measuring and Managing Employer Brand Image in the Service Industry, Journal of Marketing Management 22 (7-8), 695-716.

Lloyd, S. (2002). Branding from the Inside Out, Business Review Weekly, 24 (10), 64-66.

Martin, G. and Beaumont, P. (2003), Branding and People Management, CIPD Research Report, CIPD, London.

Martin, G., Gollan, P.J., and Grigg, K. (2011). Is There a Bigger and Better Future for Employer Branding? Facing up to Innovation, Corporate Reputations and Wicked Problems in SHRM, International Journal of Human Resource Management 22 (17), 3618-3637. ISSN 0958-5192

Morokane, P., Chiba, M., and Kleyn, N. (2016). Drivers of Employee Propensity to Endorse Their Corporate Brand, Journal of Brand Management 23(1), 55-66.

Moroko, L., and Uncles, M. (2008). Characteristics of Successful Employer Brands, Journal of Brand Management 16 (3), 160-175.

Nunnally, J. C. (1978). Psychometric theory (2nd ed.). New York: McGraw-Hill.

Phillips, T. (2017). The $\$ 900$ bn questions: What is the Belt and Road Initiative?, The Guardian International Edition, 12 May. Available at: https://www.theguardian.com/world/2017/may/12/the-900bnquestion-what-is-the-belt-and-road-initiative accessed at 08.05.2018.

Rampl, Viktoria L., and Kenning, P. (2014). Employer Brand Trust and Affect: Linking Brand Personality to Employer Brand Attractiveness, European Journal of Marketing 48 (1/2), 218-236.

van Riel, C.B.M., and Fombrun, C.J. (2007). Essentials of Corporate Communication. Abingdon: Routledge.

Simons, S. (2000). Employer of choice checklist. [online]URL: http://www.seek.com.au/editorial/0-519_work_culture.htm

Sutherland, M.M., Torricelli, D. G., and Karg, R. F. (2002). Employer-of-Choice Branding for Knowledge Workers, South African Journal of Business Management 33 (4), 13-20.

Tekin Koru, A., and Dinçer, N. N. (2018). Türkiye'de Sanayi ve Hizmet Sektörleri, İktisat ve Toplum (88), 5-11.

Turkish Statistical Institute (2019). Labour Force Statistics, 24 June. Available at: http://www.turkstat.gov.tr/UstMenu.do?metod=kategorist.

Walsh G., and Betty, S. (2007). Customer-based Corporate Reputation of a Service Firm: Scale Development and Validation, Journal of Marketing Science (35), 127-145. 